\title{
Did the Establishment of Poyang Lake Eco-Economic Zone Increase Agricultural Labor Productivity in Jiangxi Province, China?
}

\author{
Tao $\mathrm{Wu}^{1}$ and Yuelong Wang ${ }^{2, *}$ \\ Received: 10 December 2015; Accepted: 21 December 2015; Published: 24 December 2015 \\ Academic Editor: Marc A. Rosen \\ 1 School of Economics, Jiangxi University of Finance and Economics, 169 Shuanggang East Road, \\ Nanchang 330013, China; wutao@jxufe.edu.cn \\ 2 Center for Regulation and Competition, Jiangxi University of Finance and Economics, 169 Shuanggang \\ East Road, Nanchang 330013, China \\ * Correspondence: wangyuelong@jxufe.edu.cn; Tel.: +86-0791-83816310
}

\begin{abstract}
In this paper, we take the establishment of Poyang Lake Eco-Economic Zone in 2009 as a quasi-natural experiment, to evaluate its influence on the agricultural labor productivity in Jiangxi Province, China. The estimation results of the DID method show that the establishment of the zone reduced agricultural labor productivity by 3.1\%, lowering farmers' net income by $2.5 \%$ and reducing the agricultural GDP by $3.6 \%$. Furthermore, this negative effect has increased year after year since 2009. However, the heterogeneity analysis implies that the agricultural labor productivities of all cities in Jiangxi Province will ultimately converge. We find that the lack of agricultural R\&D activities and the abuse of chemical fertilizers may be the main reasons behind the negative influence of the policy, by examining two possible transmission channels-the R\&D investment and technological substitution. Corresponding policy implications are also provided.
\end{abstract}

Keywords: Poyang Lake Eco-Economic Zone; agricultural labor productivity; DID method; R\&D on agriculture

\section{Introduction}

Poyang Lake, which is located in the northern part of Jiangxi Province and connects to the lower Yangtze River, is the largest freshwater lake in China. It provides the residential and industrial water use for almost half of the regions of Jiangxi Province, especially as a water source for the production of agriculture industry. On 11 September 2008, The Standing Committee of Jiangxi Provincial Party reviewed "the Planning of Poyang Lake Eco-Economic Zone" and then submitted it to the State Council of China. According to the planning document, the Poyang Lake Eco-Economic Zone includes the three cities of Nanchang, Jiujiang, Jingdezhen, and a total of 38 counties, including some counties from Yingtan, Xinyu, Fuzhou, Yichun, Shangrao and Ji'an. The objective of the zone is to maintain sustainable environmental, social, and economic development. In December 2009, the State Council gave an official statement to support the establishment of Poyang Lake Eco-Economic Zone. After that, the central government of China provided more subsidies to the farmers in the zone and allocated more fiscal funds to Jiangxi Province.

Due to its exogeneity, we can take the establishment of Poyang Lake Eco-Economic Zone in 2009 as a quasi-natural experiment. In this paper, we use the DID method to evaluate its influence on agricultural labor productivity. The estimation results of the DID method show that the establishment of the zone reduced agricultural labor productivity by $3.1 \%$. In terms of agricultural development, 
the establishment of the zone caused farmers' net income to be reduced by $2.5 \%$ and agricultural GDP by $3.6 \%$.

Then we give the analysis of heterogeneity. We identify the agricultural labor productivities of food crops and other multiple crops, and study the dynamic changes in policy over time. The results show that the labor productivities of food crops and multiple crops did not reduce significantly and the negative effect of the zone on the agricultural labor productivity has increased year after year since 2009. However, the agricultural labor productivities of all cities in Jiangxi Province will ultimately converge during the progress of economic development.

To explain the reasons for the negative influence of the policy, we analyze two different transmission channels of the influence: the R\&D investment and technological substitution. We find that, due to the low efficiency in allocating fiscal funds, the significant growth of fiscal funds into Jiangxi Province does not promote the improvement of the agricultural labor productivity. On the other hand, farmers increase the use of new technology (e.g., fertilizer) to substitute for the labor force, thereby inhibiting the progress of agricultural labor productivity. Hence, the lack of agricultural R\&D activities and the abuse of chemical fertilizers may be the main reasons behind the negative influence.

The paper is organized as follows. A literature review is given in Section 2. Section 3 introduces the estimation methodology and data. Section 4 gives the main results of an empirical analysis. Section 5 provides the policy implications. Finally, Section 6 concludes.

\section{Literature Review}

One can find many scholars contributing to the studies of determinant factors of agricultural labor productivity. Hayami [1] and Hayami et al. [2] are the pioneers who initiated studies of agricultural labor productivity differences among countries. They identify the sources of the agriculture productivity gap using international data. Kawagoe et al. [3] give a closer look at the difference in agricultural labor productivity between developed countries and less developed countries. Instead of labor productivity, researchers also provide the analysis of total factor productivity growth in agriculture [4,5]. Another important branch of literature focuses on the relationship between R\&D activities and the growth of agricultural labor productivity. The long-run effects of agricultural research on the productivity growth are estimated [6-8]. On the other hand, some scholars study the relationship between farm size and agricultural labor productivity $[9,10]$.

In relation to the empirical research of agricultural labor productivity in China, Rozelle et al. [11] and Bhattacharyya et al. [12] believe that migration plays an important role in the determination of agricultural labor productivity, because there is a huge labor force migrating out of agriculture during the process of urbanization in China. Other empirical studies focus on the effects of economic reform after the 1980s $[13,14]$ and regional disparity $[15,16]$ on China's agricultural labor productivity. Among all of those studies, few of them focus on the determination of agricultural labor productivity in Jiangxi Province, especially after the establishment of Poyang Lake Eco-Economic Zone in 2009.

The economic and social effects of Poyang Lake Eco-Economic Zone are analyzed by some scholars. Xie et al. $[17,18]$ discuss the ecological land use in Poyang Lake Eco-Economic Zone. Chen et al. [19] give a case study for Poyang Lake to discuss the sustainable land use and economic development. Other related research focuses on either biochar utilization [20,21] or forest protection [22] in Poyang Lake Eco-Economic Zone. However, empirical study on the economic influence of Poyang Lake Eco-Economic Zone on agricultural productivity is still lacking. This study aims to fill this gap by using the DID method to estimate the influence of the policy on agricultural labor productivity, which will provide policy implications for agricultural development in Jiangxi Province. 


\section{Estimation Methodology and Data}

\subsection{Estimation Methodology}

The main scope of Poyang Lake Eco-Economic Zone is the five nearby cities of Nanchang, Jiujiang, Yingtan, Shangrao, and Jingdezhen, that locate closely to the center of the Poyang Lake; therefore, we chose these five cities as the component parts of Poyang Lake Eco-Economic Zone. Another reason to make this classification is that we use city-level data to estimate the influence of policy. We have to separate the 11 cities of Jiangxi Province into either the treatment group or reference group to match with the data. Hence, the five cities (i.e., Nanchang, Jiujiang, Yingtan, Shangrao, and Jingdezhen) are chosen for the treatment group of our evaluation, and the other six cities in Jiangxi Province (i.e., Fuzhou, Yichun, Ji'an, Pingxiang, Ganzhou, and Xinyu) are chosen as the reference group. By using DID estimation, the econometric model is set as follows:

$$
y_{i t}=\alpha_{i}+\gamma_{t}+\beta_{1} \times d u+\beta_{2} \times d t+\beta_{3} \times d u \times d t+X \theta
$$

We used the panel data of 11 cities in Jiangxi Province from 2005 to 2013 to estimate Equation (1). In Equation (1), $y_{i t}$ is the agricultural labor productivity, which equals agricultural GDP divided by agricultural labor force (denoted as productivity). $\alpha_{i}$ and $\gamma_{t}$ represent the city-fixed effects and the time-fixed effects, respectively. $d u$ is the group dummy variable; $d u=1$ for the cities of Nanchang, Jiujiang, Yingtan, Shangrao, and Jingdezhen in the treatment group, and $d u=0$ for the cities of Fuzhou, Yichun, Ji'an, Pingxiang, Ganzhou, and Xinyu in the reference group. $d t$ is the time dummy variable; $d t=0$ for 2005-2008, before the implementation of the policy, and $d t=1$ for 2009-2013, after the implementation of the policy. The coefficient $\beta_{3}$ of the interaction term $d u \times d t$ is our main focus of the policy effect. $X$ is a set of control variables: we control the proportion of primary industry in GDP (denoted as ratio_agriculture), trade openness (i.e., the total volume of foreign trade divided by total GDP, denoted as trade), the share of infrastructural investment in GDP (denoted as invest_infrastructure), the share of agricultural fixed capital investment in GDP (denoted as invest_agriculture), and foreign direct investment (denoted as fdi).

\subsection{Data}

The panel data for 11 cities in Jiangxi Province from 2005 to 2013 were collected from the Jiangxi Statistical Yearbook [23]. To avoid the problem of heteroscedasticity, we take the natural logarithms of all data except proportions. All the data related to prices have been deflated, by choosing year 2005 as the reference base year. The descriptive statistics of the main variables in the paper are shown in Table 1.

Table 1. Descriptive statistics of variables.

\begin{tabular}{|c|c|c|c|c|c|c|}
\hline Variables (units) & Mean & ST.D. & Median & Min & Max & Samples \\
\hline ratio_agriculture (\%) & 14 & 6.4 & 12.78 & 4.71 & 27.5 & 99 \\
\hline invest_infrastructure (\%) & 2.43 & 1.99 & 1.69 & 0.36 & 10.62 & 99 \\
\hline expenditure_agriculture $(10,000 \mathrm{RMB})$ & $1.6 \times 10^{5}$ & $1.5 \times 10^{5}$ & $1.1 \times 10^{5}$ & 6563 & $6.1 \times 10^{5}$ & 99 \\
\hline expenditure_rEd $(10,000 \mathrm{RMB})$ & 5159 & 13,504 & 929 & 31 & 70,754 & 99 \\
\hline fertilizer (ton/10,000 RMB) & 0.38 & 0.12 & 0.36 & 0.17 & 0.64 & 99 \\
\hline pesticide (ton/10,000 RMB) & 0.01 & 0.00 & 0.01 & 0.00 & 0.02 & 99 \\
\hline income_agriculture (RMB) & 5768 & 2133 & 5077 & 2760 & 11,173 & 99 \\
\hline gdp_agriculture $(10,000 \mathrm{RMB})$ & $9.8 \times 10^{5}$ & $6.2 \times 10^{5}$ & $8.8 \times 10^{5}$ & $1.7 \times 10^{5}$ & $2.7 \times 10^{6}$ & 99 \\
\hline productivity_food (RMB/capita) & 3902 & 1214 & 3902 & 1122 & 6411 & 98 \\
\hline
\end{tabular}


The time trends of agricultural labor productivity for 2005-2013 inside and outside the Poyang Lake Eco-Economic Zone are shown in Figure 1. The solid curve, which represents the agricultural labor productivity of the treatment group, lies below the dotted curve, which represents the agricultural labor productivity of the reference group.

In Figure 1, we can see that the two curves are almost parallel before 2009, which implies that our samples satisfy the assumption of parallel trend that is required by the DID method. After 2009, one can find that growth rate of agricultural labor productivity in the Poyang Lake Eco-Economic Zone has slowed down compared to that of the reference group. This implies that the establishment of Poyang Lake Eco-Economic Zone may have a negative influence on agricultural labor productivity, which will be revealed by the following econometric analysis.

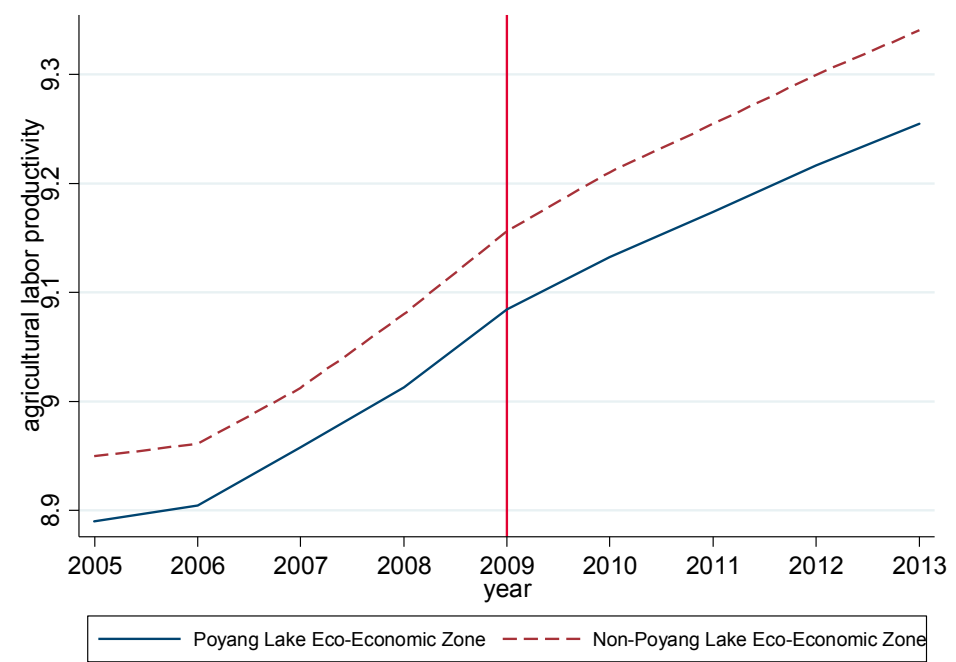

Figure 1. Time trends of agricultural labor productivity.

\section{Results}

\subsection{Benchmark}

In Table 2, the results of model 1 show that the establishment of Poyang Lake Eco-Economic Zone reduced agricultural labor productivity by $2 \%$. Furthermore, by adding some control variables, we can derive model 2. It shows that the negative effect increased up to $3.1 \%$, and is still significant at the $1 \%$ level. Out of all the control variables, only the coefficient of the proportion of primary industry (denoted as ratio_agriculture) is significantly positive, which implies that the higher the proportion of primary industry and the better the local agricultural basic conditions are, the higher the labor productivity is. We also give a placebo test to verify that the establishment of Poyang Lake Eco-Economic Zone in 2009, instead of any other policies, lowered the agricultural labor productivity. By assuming that the policy occurred in 2007 (i.e., $d t 0=1$ for 2007 and 2008; $d t 0=0$ for 2005 and $2006)$, we find that the coefficient of interaction term $\left(\beta_{3}\right)$ representing the policy influence in model 3 is not significant. Hence, we can conclude that agricultural labor productivity decreased after 2009, due to the establishment of the Poyang Lake Eco-Economic Zone. 
Table 2. Benchmark model.

\begin{tabular}{|c|c|c|c|}
\hline \multirow{2}{*}{ Variables } & Model 1 & Model 2 & Model 3 \\
\hline & Lnproductivity & Lnproductivity & Lnproductivity \\
\hline$d u$ & $\begin{array}{c}0.306^{* * *} \\
(37.15)\end{array}$ & $\begin{array}{c}0.390 * * * \\
(8.04)\end{array}$ & $\begin{array}{c}0.398^{* * *} \\
(4.85)\end{array}$ \\
\hline$d t$ & $\begin{array}{c}0.388^{* * *} \\
(35.44)\end{array}$ & $\begin{array}{c}0.428^{* * *} \\
(21.32)\end{array}$ & \\
\hline$d u \times d t$ & $\begin{array}{c}-0.0203^{* * *} \\
(-2.76)\end{array}$ & $\begin{array}{c}-0.0311^{* * *} \\
(-3.82)\end{array}$ & \\
\hline invest_agriculture & & $\begin{array}{c}0.000821 \\
(0.23)\end{array}$ & $\begin{array}{l}-0.0201 \\
(-0.98)\end{array}$ \\
\hline ratio_agriculture & & $\begin{array}{c}0.00619 \text { *** } \\
(2.87)\end{array}$ & $\begin{array}{c}0.00569 \\
(1.65)\end{array}$ \\
\hline invest_infrastructure & & $\begin{array}{c}-0.000906 \\
(-0.64)\end{array}$ & $\begin{array}{c}0.00532 \\
(0.78)\end{array}$ \\
\hline trade & & $\begin{array}{c}1.58 \times 10^{-5} \\
(0.04)\end{array}$ & $\begin{array}{c}-0.000302 \\
(-1.52)\end{array}$ \\
\hline $\ln f d i$ & & $\begin{array}{c}0.00816 \\
(0.45)\end{array}$ & $\begin{array}{c}0.00476 \\
(0.33)\end{array}$ \\
\hline$d t 0$ & & & $\begin{array}{c}0.159 * * * \\
(9.36)\end{array}$ \\
\hline$d u \times d t 0$ & & & $\begin{array}{l}-0.0139 \\
(-1.56)\end{array}$ \\
\hline Constant & $\begin{array}{l}8.870 * * * \\
(791.18)\end{array}$ & $\begin{array}{c}8.624^{* * *} \\
(40.42)\end{array}$ & $\begin{array}{c}8.654^{* * *} \\
(54.41)\end{array}$ \\
\hline Individual fixed effects & Yes & Yes & Yes \\
\hline Time fixed affects & Yes & Yes & Yes \\
\hline Observations & 99 & 93 & 40 \\
\hline R-squared & 0.995 & 0.995 & 0.998 \\
\hline
\end{tabular}

Note: $(1)^{* * *}, * *$, and $*$ represent the significance at the $1 \%, 5 \%$, and $10 \%$ levels; (2) the $t$-statistics in parentheses are given by three heteroscedastic robustness standard errors.

\subsection{Heterogeneity Analysis}

Did the establishment of Poyang Lake Eco-Economic Zone causes reduction of agricultural labor productivity in terms of all agricultural products? To answer this question, models 4 and 5 in Table 3 study the influences of the establishment on the labor productivity of food crops (denoted as productivity_food) and that of multiple crops (denoted as productivity_multi). Both results are negative but not significant, which implies that the negative effects do not exist in the production process of food crops and multiple crops.

Table 3. Heterogeneity analysis.

\begin{tabular}{cccccc}
\hline \multirow{2}{*}{ Variables } & Model 4 & Model 5 & Model 6 & Model 7 & Model 8 \\
\cline { 2 - 6 } & Lnfood & Lnmulti & Lnproductivity & Lnproductivity & Lnproductivity \\
\hline \multirow{2}{*}{$d u$} & 0.231 & 0.392 & $0.389^{* * *}$ & $0.392^{* * *}$ & $0.387^{* * *}$ \\
& $(0.93)$ & $(1.58)$ & $(8.12)$ & $(8.08)$ & $(7.84)$ \\
\hline \multirow{2}{*}{$d t$} & $0.656^{* * *}$ & $0.656^{* * *}$ & $0.427^{* * *}$ & $0.430^{* * *}$ & $0.436^{* * *}$ \\
& $(6.15)$ & $(6.15)$ & $(21.57)$ & $(21.21)$ & $(20.80)$ \\
\hline
\end{tabular}


Table 3. Cont.

\begin{tabular}{|c|c|c|c|c|c|}
\hline \multirow{2}{*}{ Variables } & Model 4 & Model 5 & Model 6 & Model 7 & Model 8 \\
\hline & Lnfood & Lnmulti & Lnproductivity & Lnproductivity & Lnproductivity \\
\hline policy 2009 & & & & & $\begin{array}{c}-0.0212^{* *} \\
(-2.61)\end{array}$ \\
\hline policy 2010 & & & & & $\begin{array}{c}-0.0312^{* * *} \\
(-2.93)\end{array}$ \\
\hline policy 2011 & & & & & $\begin{array}{c}-0.0327^{* *} \\
(-2.26)\end{array}$ \\
\hline policy 2012 & & & & & $\begin{array}{c}-0.0369^{* *} \\
(-2.54)\end{array}$ \\
\hline policy 2013 & & & & & $\begin{array}{c}-0.0433^{* * *} \\
(-3.29)\end{array}$ \\
\hline invest_agriculture & $\begin{array}{c}-0.0378^{* * *} \\
(-3.20)\end{array}$ & $\begin{array}{c}-0.0378^{* * *} \\
(-3.20)\end{array}$ & $\begin{array}{c}0.000726 \\
(0.20)\end{array}$ & $\begin{array}{c}0.000577 \\
(0.16)\end{array}$ & $\begin{array}{c}-0.000679 \\
(-0.17)\end{array}$ \\
\hline ratio_agriculture & $\begin{array}{l}0.0164 \\
(1.39)\end{array}$ & $\begin{array}{c}0.0164 \\
(1.39)\end{array}$ & $\begin{array}{l}0.00616^{* * * *} \\
(2.87)\end{array}$ & $\begin{array}{c}0.00633^{* * *} \\
(2.94)\end{array}$ & $\begin{array}{c}0.00667^{* * *} \\
(3.16)\end{array}$ \\
\hline invest_infrastructure & $\begin{array}{c}0.00105 \\
(0.19)\end{array}$ & $\begin{array}{c}0.00105 \\
(0.19)\end{array}$ & $\begin{array}{c}-0.000871 \\
(-0.62)\end{array}$ & $\begin{array}{c}-0.000838 \\
(-0.59)\end{array}$ & $\begin{array}{c}-0.000518 \\
(-0.33)\end{array}$ \\
\hline trade & $\begin{array}{c}-0.000231 \\
(-0.20)\end{array}$ & $\begin{array}{c}-0.000231 \\
(-0.20)\end{array}$ & $\begin{array}{c}1.28 \times 10^{-5} \\
(0.03)\end{array}$ & $\begin{array}{c}9.91 \times 10^{-6} \\
(0.03)\end{array}$ & $\begin{array}{c}-5.34 \times 10^{-5} \\
(-0.13)\end{array}$ \\
\hline $\ln f d i$ & $\begin{array}{l}0.0269 \\
(0.33) \\
\end{array}$ & $\begin{array}{c}0.0269 \\
(0.33)\end{array}$ & $\begin{array}{c}0.00858 \\
(0.47)\end{array}$ & $\begin{array}{c}0.00841 \\
(0.47) \\
\end{array}$ & $\begin{array}{c}0.0122 \\
(0.64)\end{array}$ \\
\hline policy & $\begin{array}{l}-0.0508 \\
(-1.10) \\
\end{array}$ & $\begin{array}{l}-0.0508 \\
(-1.10) \\
\end{array}$ & & & \\
\hline policy_gdp & & & $\begin{array}{c}-0.00231^{* * *} \\
(-3.90)\end{array}$ & & \\
\hline policy_income & & & & $\begin{array}{c}-0.00358^{* * *} \\
(-3.84) \\
\end{array}$ & \\
\hline Constant & $\begin{array}{c}7.530 * * * \\
(7.73)\end{array}$ & $\begin{array}{c}8.405^{* * *} \\
(8.63)\end{array}$ & $\begin{array}{c}8.620 * * * \\
(40.34)\end{array}$ & $\begin{array}{c}8.618^{* * *} \\
(40.49) \\
\end{array}$ & $\begin{array}{c}8.568^{* * *} \\
(38.22)\end{array}$ \\
\hline $\begin{array}{l}\text { Individual fixed } \\
\text { effects }\end{array}$ & Yes & Yes & Yes & Yes & Yes \\
\hline Time fixed effects & Yes & Yes & Yes & Yes & Yes \\
\hline Observations & 93 & 93 & 93 & 93 & 93 \\
\hline R-squared & 0.970 & 0.938 & 0.995 & 0.995 & 0.995 \\
\hline
\end{tabular}

Then, we introduce the interaction term of policy and agricultural GDP (denoted as policy_gdp), and the interaction term of policy and farmers' net income (denoted as policy_income) in models 6 and 7 , respectively. We can see that both coefficients of the interaction terms are significantly negative, which implies that in the regions of higher agricultural GDP and farmers' net income (i.e., regions of higher agricultural development), the reduction of the agricultural labor productivity caused by the policy is higher. Taking these effects into consideration, we can predict that the agricultural labor productivities of all cities in Jiangxi Province will ultimately converge during the progress of agricultural development. By adding in dummy variables for the interaction terms of the policy as well as each year from 2009 to 2013, model 8 examines the effect of the policy on dynamic heterogeneity over time. The results show that after the establishment of Poyang Lake Eco-Economic Zone, the negative effect increased year after year. 


\subsection{Analysis of Transmission Channels}

Because labor productivity is mutually influenced by the allocation of the government's funds and the substitution of labor by new technologies (or new materials), we analyze two possible transmission channels of the policy influence: R\&D investment and technological substitution.

Models 9 and 11 in Table 4 give the DID estimations of fiscal expenditure on agriculture (denoted as expenditure_agriculture) and R\&D expenditure (denoted as expenditure_r $\& d$ ), respectively. The results show that after the establishment of Poyang Lake Eco-Economic Zone in 2009, the government's fiscal expenditure on agriculture in Jiangxi Provence increased by $6.9 \%$, but there is no obvious change in the R\&D expenditure of Jiangxi Provence. Then, on the basis of model 2, by adding two possible channel variables (i.e., expenditure_agriculture and expenditure_rEd), we got models 10 and 12. The estimated coefficient of the policy interaction term in model 10 does not change significantly, compared to that of model 2. However, the estimated coefficient of the policy interaction term in model 12 has changed significantly; meanwhile, the coefficient of the R\&D expenditure is significantly negative. As a conclusion, the establishment of Poyang Lake Eco-Economic Zone does not promote agricultural labor productivity through government fiscal expenditure. There is no corresponding increase in R\&D expenditure because of the inappropriate use of fiscal funds, which results in a lack of R\&D activities on agriculture and a reduction of agricultural labor productivity.

Table 4. Transmission channel I: R\&D investment.

\begin{tabular}{|c|c|c|c|c|}
\hline \multirow{2}{*}{ Variables } & Model 9 & Model 10 & Model 11 & Model 12 \\
\hline & Lnexpenditure_Agriculture & Lnproductivity & Lnexpenditure_RED & Lnproductivity \\
\hline$d u$ & $\begin{array}{c}-0.408^{* *} \\
(-2.09)\end{array}$ & $\begin{array}{c}0.397^{* * * *} \\
(8.18)\end{array}$ & $\begin{array}{c}5.526^{* * * *} \\
(8.37)\end{array}$ & $\begin{array}{c}0.447^{* * * *} \\
(10.18)\end{array}$ \\
\hline$d t$ & $\begin{array}{l}2.512^{* * * *} \\
(21.15)\end{array}$ & $\begin{array}{c}0.345^{* * * *} \\
(5.15)\end{array}$ & $\begin{array}{c}1.592^{* * * *} \\
(4.29)\end{array}$ & $\begin{array}{c}0.434^{* * *} \\
(24.56)\end{array}$ \\
\hline$d u \times d t$ & $\begin{array}{c}0.0692 * \\
(1.71)\end{array}$ & $\begin{array}{c}-0.0309 * * * \\
(-3.71)\end{array}$ & $\begin{array}{c}-0.000990 \\
(-0.01)\end{array}$ & $\begin{array}{c}-0.0270 * * * \\
(-3.36)\end{array}$ \\
\hline Inexpenditure_agriculture & & $\begin{array}{l}0.0310 \\
(1.40) \\
\end{array}$ & & \\
\hline invest_agriculture & & $\begin{array}{c}0.00182 \\
(0.50)\end{array}$ & & $\begin{array}{c}0.00361 \\
(1.16)\end{array}$ \\
\hline ratio_agriculture & $\begin{array}{l}-0.0211 \\
(-1.62)\end{array}$ & $\begin{array}{c}0.00683^{* * * *} \\
(3.04)\end{array}$ & $\begin{array}{l}0.0895^{* *} \\
(2.34)\end{array}$ & $\begin{array}{c}0.00683^{* * * *} \\
(3.34)\end{array}$ \\
\hline invest_infrastructure & & $\begin{array}{c}-0.00105 \\
(-0.74)\end{array}$ & & $\begin{array}{c}-0.000774 \\
(-0.58)\end{array}$ \\
\hline trade & & $\begin{array}{c}-1.66 \times 10^{-5} \\
(-0.04)\end{array}$ & & $\begin{array}{c}-0.000240 \\
(-0.51)\end{array}$ \\
\hline $\ln f d i$ & & $\begin{array}{c}0.0108 \\
(0.60)\end{array}$ & & $\begin{array}{l}0.0128 \\
(0.73)\end{array}$ \\
\hline Inexpenditure_rEd & & & & $\begin{array}{c}-0.0128 \text { *** } \\
(-2.67)\end{array}$ \\
\hline Constant & $\begin{array}{c}10.66^{* * * *} \\
(31.18)\end{array}$ & $\begin{array}{l}8.265^{* * * *} \\
(23.08)\end{array}$ & $\begin{array}{c}3.661^{* * * *} \\
(3.64)\end{array}$ & $\begin{array}{c}8.632 * * * \\
(43.39)\end{array}$ \\
\hline Individual fixed effects & Yes & Yes & Yes & Yes \\
\hline Time fixed effects & Yes & Yes & Yes & Yes \\
\hline Observations & 99 & 93 & 99 & 93 \\
\hline R-squared & 0.994 & 0.995 & 0.944 & 0.995 \\
\hline
\end{tabular}

The output of agricultural products depends on the input of production factors such as labor and land, and also depends on the use of new production technologies. Due to the availability of 
data, we use the chemical fertilizer usage per unit of agricultural GDP (denoted as fertilizer) and the pesticide usage per unit of agricultural GDP (denoted as pesticide) to study the transmission channels of technological substitution. Models 13 and 15 in Table 5 show that after Poyang Lake Eco-Economic Zone was established in 2009, the chemical fertilizer usage per unit of agricultural GDP significantly increased by $3.1 \%$; meanwhile, there was no obvious change in the use of pesticides. Based on model 2, we get models 14 and 16 by adding two possible channel variables (i.e., fertilizer and pesticide). The estimated coefficient of the policy interaction term in model 14 is significantly different from that in model 2, and the use of chemical fertilizers has an insignificantly negative effect on the agricultural labor productivity. Meanwhile, there is no obvious change in the coefficient of the policy interaction term in model 16, compared to model 2. We can explain the estimation results in the following way. After the establishment of Poyang Lake Eco-Economic Zone in 2009, farmers used more new production technology, such as chemical fertilizers, to substitute for labor input. In the short run, the utilization of chemical fertilizer increased the output of agricultural products. However, it causes pollution of waterway, acidification and mineral depletion of the soil, therefore damages the value of agricultural products. The utilization of chemical fertilizer will reduce the growth rate of agricultural GDP, thus resulting in a loss of agricultural labor productivity in the long run.

Table 5. Transmission channel II: technological substitution.

\begin{tabular}{|c|c|c|c|c|}
\hline \multirow{2}{*}{ Variables } & Model 13 & Model 14 & Model 15 & Model 16 \\
\hline & Fertilizer & Lnproductivity & Pesticide & Lnproductivity \\
\hline$d u$ & $\begin{array}{c}-0.186^{* * *} \\
(-13.53)\end{array}$ & $\begin{array}{c}0.373^{* * *} \\
(7.16)\end{array}$ & $\begin{array}{c}-0.00571^{* * * *} \\
(-6.06)\end{array}$ & $\begin{array}{c}0.391^{* * *} \\
(7.73)\end{array}$ \\
\hline$d t$ & $\begin{array}{c}-0.295^{* * *} \\
(-24.14)\end{array}$ & $\begin{array}{c}0.400^{* * *} \\
(13.54)\end{array}$ & $\begin{array}{c}-0.00539 * * * \\
(-7.24)\end{array}$ & $\begin{array}{c}0.428^{* * *} \\
(19.20)\end{array}$ \\
\hline$d u \times d t$ & $\begin{array}{c}0.0310 * * \\
(2.40)\end{array}$ & $\begin{array}{c}-0.0274 * * * \\
(-3.42)\end{array}$ & $\begin{array}{c}-3.17 \times 10^{-5} \\
(-0.04)\end{array}$ & $\begin{array}{c}-0.0311^{* * *} \\
(-3.80)\end{array}$ \\
\hline fertilizer & & $\begin{array}{l}-0.116 \\
(-1.43)\end{array}$ & & \\
\hline invest_agriculture & & $\begin{array}{c}-0.000293 \\
(-0.08)\end{array}$ & & $\begin{array}{c}0.000833 \\
(0.23)\end{array}$ \\
\hline ratio_agriculture & & $\begin{array}{c}0.00629^{* * *} \\
(3.02)\end{array}$ & & $\begin{array}{c}0.00620^{* * *} \\
(2.80)\end{array}$ \\
\hline invest_infrastructure & & $\begin{array}{c}-0.000991 \\
(-0.73)\end{array}$ & & $\begin{array}{c}-0.000912 \\
(-0.63)\end{array}$ \\
\hline trade & & $\begin{array}{c}-9.87 \times 10^{-5} \\
(-0.27)\end{array}$ & & $\begin{array}{c}1.37 \times 10^{-5} \\
(0.04)\end{array}$ \\
\hline $\ln f d i$ & & $\begin{array}{c}0.00799 \\
(0.42)\end{array}$ & & $\begin{array}{c}0.00806 \\
(0.45)\end{array}$ \\
\hline pesticide & & & & $\begin{array}{c}0.0740 \\
(0.05)\end{array}$ \\
\hline Constant & $\begin{array}{c}1.292 * * * \\
(4.99)\end{array}$ & $\begin{array}{c}8.699 * * * \\
(36.17)\end{array}$ & $\begin{array}{c}0.0596^{* * *} \\
(4.76)\end{array}$ & $\begin{array}{c}8.624^{* * *} \\
(40.00)\end{array}$ \\
\hline Individual effect & Yes & Yes & Yes & Yes \\
\hline Time trends & Yes & Yes & Yes & Yes \\
\hline Observation & 98 & 93 & 98 & 93 \\
\hline R-squared & 0.963 & 0.995 & 0.798 & 0.995 \\
\hline
\end{tabular}

Note: $(1)^{* * *},{ }^{* *}$, and * represent the significance at the $1 \%, 5 \%$, and $10 \%$ levels; (2) the $t$-statistics in parentheses are given by heteroscedastic robustness standard errors. 


\subsection{Effects on Agriculture Development}

The reduction of agricultural labor productivity will directly slow the growth rate of farmers' income and agricultural development. Hence, we provide a further study of the effects of agricultural labor productivity on agricultural development. We use farmers' net income (denoted as income_agriculture) and agricultural GDP (denoted as gdp_agriculture) as indicators of agricultural development. The estimation results of models 17 and 18 in Table 6 show that as agricultural labor productivity increases by $1 \%$, farmers' net income increases by $0.81 \%$ and agricultural GDP increases by $1.1 \%$. Recall that in model 2, we have shown that the establishment of Poyang Lake Eco-Economic Zone reduced agricultural labor productivity by $3.1 \%$. Hence, the establishment of the zone reduced farmers' net income by $2.5 \%$ and agricultural GDP by $3.6 \%$.

Table 6. The effects on agricultural development.

\begin{tabular}{ccc}
\hline \multirow{2}{*}{ Variables } & Model 17 & Model 18 \\
\cline { 2 - 3 } & Lnincome_Agriculture & Lngdp_Agriculture \\
\hline \multirow{2}{*}{ Inpgdp } & $0.130^{* * *}$ & \\
\hline ratio_employ & $(3.15)$ & \\
\hline Inproductivity & $(1.20)$ & \\
\hline Inemploy_agriculture & $0.808^{* * *}$ & $1.100 * * *$ \\
& $(3.66)$ & $(3.24)$ \\
\hline Ingdp & & 0.153 \\
& & $(1.37)$ \\
\hline Constant & & 0.139 \\
& & $(1.43)$ \\
\hline Individual effect & -0.445 & 0.503 \\
Time trends & $(-0.21)$ & $(0.14)$ \\
\hline Observations & Yes & Yes \\
\hline R-squared & 98 & Yes \\
\hline
\end{tabular}

Note: $(1)^{* * *}, * *$, and ${ }^{*}$ represent the significance at the $1 \%, 5 \%$, and $10 \%$ levels; (2) the $t$-statistics in parentheses are given by heteroscedastic robustness standard errors.

\section{Policy Implications}

Based on the results of our analysis, the government should focus on reversing the negative impact of Poyang Lake Eco-Economic Zone on agricultural labor productivity to improve social welfare and agricultural development. The policy implications are as follows: 1) increase the proportion of R\&D expenditure in Jiangxi Province, especially to encourage the R\&D activities related to agricultural technologies and the primary industry in Poyang Lake Eco-Economic Zone; 2) issue a series of incentive-compatible subsidy policies to encourage farmers to reduce the excess usage of chemical fertilizers, and increase the values of agricultural products in the long run; 3 ) to shift the industry focus from manufacture to tourism by regulation, which will cause a positive externality on agricultural development. The combination of these policies will increase farmers' income and encourage agricultural development by improving agricultural labor productivity.

\section{Conclusions}

In this paper, we use the establishment of the Poyang Lake Eco-Economic Zone in 2009 as a quasi-natural experiment to evaluate its influence on the agricultural labor productivity in Jiangxi 
Province, China. The estimation results of the DID method show that the establishment of the zone reduced agricultural labor productivity by $3.1 \%$. Hence, the establishment of the zone caused a negative influence on agriculture development, reducing the farmers' net income by $2.5 \%$ and the agricultural GDP by $3.6 \%$. The analysis of heterogeneity implies that this negative effect has increased year after year since2009, and the agricultural labor productivities of all cities in Jiangxi Province will ultimately converge. We also examine two possible transmission channels (i.e., R\&D investment and technological substitution) to show that the main reasons behind the negative policy influence may be the lack of agricultural $R \& D$ activities and the abuse of chemical fertilizers.

Because the establishment of Poyang Lake Eco-Economic Zone in 2009 can be taken as a quasi-natural experiment, we can also apply the similar DID method to analyze the influence of policy on total factor productivity in Jiangxi Province. Another interesting further extension would be the relationship between agricultural labor productivity and water resources of Poyang Lake, which play an important role in agricultural production and are also greatly influenced by the planning of Poyang Lake Eco-Economic Zone.

Acknowledgments: Yuelong Wang would like to acknowledge the financial support from the University Youth Project 2014 of Humanities and Social Science Research in Jiangxi Province (\#JJ1444), the Key Base Project 2014 of Humanities and Social Science in Jiangxi Province (\#JD1454), and the Science and Technology Project 2016 of Jiangxi Provincial Department of Education, "Public Investment and Urban Development".

Author Contributions: Tao Wu conceived and designed the study, also devoted to the writing of the paper; Yuelong Wang collected and analyzed the data.

Conflicts of Interest: The authors declare no conflict of interest.

\section{References}

1. Hayami, Y. Sources of agricultural productivity gap among selected countries. Am. J. Agric. Econ. 1969, 51, 564-575.

2. Hayami, Y.; Ruttan, V.W. Agricultural productivity differences among countries. Am. Econ. Rev. 1970, 60, 895-911.

3. Kawagoe, T.; Hayami, Y.; Ruttan, V.W. The intercountry agricultural production function and productivity differences among countries. J. Dev. Econ. 1985, 19, 113-132. [CrossRef]

4. Coelli, T.J.; Rao, D.S. Total factor productivity growth in agriculture: A Malmquist index analysis of 93 countries, 1980-2000. Agric. Econ. 2005, 32, 115-134. [CrossRef]

5. Restuccia, D.; Yang, D.T.; Zhu, X. Agriculture and aggregate productivity: A quantitative cross-country analysis. J. Monetary Econ. 2008, 55, 234-250. [CrossRef]

6. Alston, J.M.; Beddow, J.M.; Pardey, P.G. Agricultural research, productivity, and food prices in the long run. Science 2009, 325, 1209-1210. [CrossRef] [PubMed]

7. Thirtle, C.; Lin, L.; Piesse, J. The impact of research-led agricultural productivity growth on poverty reduction in Africa, Asia and Latin America. World Dev. 2003, 31, 1959-1975. [CrossRef]

8. Sumberg, J. Systems of innovation theory and the changing architecture of agricultural research in Africa. Food policy 2005, 30, 21-41. [CrossRef]

9. Cornia, G.A. Farm size, land yields and the agricultural production function: An analysis for fifteen developing countries. World Dev. 1985, 13, 513-534. [CrossRef]

10. Feder, G. The relation between farm size and farm productivity: The role of family labor, supervision and credit constraints. J. Dev. Econ. 1985, 18, 297-313. [CrossRef]

11. Bhattacharyya, A.; Parker, E. Labor productivity and migration in Chinese agriculture: A stochastic frontier approach. China Econ. Rev. 1999, 10, 59-74. [CrossRef]

12. Rozelle, S. J.; Taylor, J.E.; de Brauw, A. Migration, remittances, and agricultural productivity in China. Am. Econ. Rev. 1999, 89, 287-291. [CrossRef]

13. McMillan, J.; Whalley, J.; Zhu, L. The impact of China's economic reforms on agricultural productivity growth. J. Political Econ. 1989, 97, 781-807. [CrossRef]

14. Lin, J.Y. Rural reforms and agricultural growth in China. Am. Econ. Rev. 1992, 82, 34-51. 
15. Cai, F.; Wang, D.; Du, Y. Regional disparity and economic growth in China: The impact of labor market distortions. China Econ. Rev. 2002, 13, 197-212. [CrossRef]

16. Kanbur, R.; Zhang, X. Fifty years of regional inequality in China: A journey through central planning, reform, and openness. Rev. Dev. Econ. 2005, 9, 87-106. [CrossRef]

17. Xie, H.; Wang, P; Huang, H. Ecological risk assessment of land use change in the Poyang Lake eco-economic zone, China. Int. J. Environ. Res. Public Health 2003, 10, 328-346. [CrossRef] [PubMed]

18. Xie, H.; Liu, Z.; Wang, P.; Liu, G.; Lu, F. Exploring the mechanisms of ecological land change based on the spatial autoregressive model: A case study of the Poyang lake eco-economic zone, China. Int. J. Environ. Resear. Public Health 2003, 11, 583-599. [CrossRef] [PubMed]

19. Chen, W.; Carsjens, G. J.; Zhao, L.; Li, H. A spatial optimization model for sustainable land use at regional level in China: A case study for Poyang Lake region. Sustainability 2014, 7, 35-55. [CrossRef]

20. Chang, M.S.; Kung, C.C. Nonparametric forecasting for biochar utilization in Poyang Lake Eco-Economic Zone in China. Sustainability 2014, 6, 267-282. [CrossRef]

21. Kung, C.C.; Kong, F.; Choi, Y. Pyrolysis and biochar potential using crop residues and agricultural wastes in China. Ecol. Indic. 2015, 51, 139-145. [CrossRef]

22. Liu, R.Z.; Song, P.; Sheng, Q.Y.; Gong, W.J. Legal system for China's forest resource protection: A case study of Poyang Lake Eco-economic Zone. Asian Agric. Resear. 2012, 4, 65-68.

23. Statistic Bureau of Jiangxi. Jiangxi Statistical Yearbook, 2006-2014; China Statistics Press: Beijing, China, 2006-2014.

(C) 2015 by the authors; licensee MDPI, Basel, Switzerland. This article is an open access article distributed under the terms and conditions of the Creative Commons by Attribution (CC-BY) license (http://creativecommons.org/licenses/by/4.0/). 